\section{Health research networks on the web: an analysis of the Brazilian presence}

\author{
Redes de pesquisa em saúde na web: uma análise \\ da presença brasileira
}

\author{
Redes de investigación en salud en la web: un \\ análisis de la presencia brasileña
}

\begin{abstract}
In order to map Brazilian institutions' web presence in an international network of health research institutions, a study was conducted in 2009, including 190 institutions from 42 countries. The sample was based on WHO (World Health Organization) collaborating centers, and the methodology used webometric analyses and techniques, especially interlinks, and social network analysis. The results showed the presence of five Brazilian institutions, featuring the Oswaldo Cruz Foundation (Fiocruz), showing links to 20 countries and 42 institutions. Through the interface between the health field and the web, the study aims to contribute to future analyses and a plan for strategic repositioning of these institutions in the virtual world, as well as to the elaboration of public policies and recognition of webometrics as an area to be explored and applied to various other fields of knowledge.
\end{abstract}

International Cooperation; Internet; Social Networking
Pamela Barreto Lang 1,2 Fábio Castro Gouveia 3 Jacqueline Leta 2

\section{Resumo}

Com a finalidade de mapear na web a presença de instituições brasileiras em uma rede internacional de instituições de pesquisa no campo da saúde, foi realizado, em 2009, um estudo com 190 instituições, representando 42 países. A amostra foi selecionada com base nos centros colaboradores da Organização Mundial da Saúde (OMS) e a metodologia empregada se baseou em análises e técnicas webmétricas, especialmente por meio de interlinks, e de redes sociais. Os resultados mostram a presença de cinco instituições brasileiras, com destaque para a Fundação Oswaldo Cruz (Fiocruz), que apresenta conexões com 20 países e 42 instituições. Pela interface entre o campo da saúde e a web, este trabalho pretende contribuir não apenas para análises futuras e um plano de reposicionamento estratégico dessas instituições no mundo virtual, mas também para a elaboração de políticas públicas e o reconhecimento da webmetria como uma área a ser explorada e aplicada a diversos outros campos do conhecimento.

Cooperação Internacional; Internet; Rede Social 


\section{Introduction}

The socioeconomic division between economically developed countries of the North and low and middle-income countries has characterized various models of international cooperation and poses a huge challenge, particularly for global health 1 . In order to overcome foreign dependence, ensure the transfer of cutting-edge technology, and develop local health infrastructures, horizontal cooperation between countries of the South (known as South-South cooperation) has been continuously encouraged over time.

One of the first such initiatives occurred in 1972, when the United Nations General Assembly acknowledged the importance of creating a special unit for technical cooperation among developing countries (TCDC) under the United Nations Development Program (UNDP), which became a reality in 1978 during a conference on TCDC in Buenos Aires, Argentina. The Buenos Aires Action Plan identified 15 key areas for the promotion and implementation of TCDC, renamed the Special Unit for South-South Cooperation (SUSSC) in 20042

Brazil, with one of the largest economies in the South, has accompanied this trend by prioritizing South-South cooperation in the context of its international relations and by partnering with countries and international agencies for decades. In 1987, with the creation of the Brazilian Cooperation Association (ABC), the country established an effective coordinating body for cooperation among developing countries, with the objective of "coordinating, negotiating, approving, monitoring, and evaluating cooperation for development, in all areas of knowledge, both that received from other countries and international agencies and between Brazil and developing countries" 3 .

In health, policies to encourage international collaboration began more than 50 years ago, when the World Health Organization (WHO) designated institutions across the world to act as collaborating centers in health research, establishing networks for cooperation on various themes. A designated collaborating center can be the institution as a whole, or one of its departments, laboratories, or other internal divisions. There are currently some 900 WHO collaborating centers, distributed across more than 90 countries and in the six regions where the WHO maintains offices: Western Pacific 21\%; Americas 21\%; Southeast Asia 10\%; Eastern Mediterranean $6 \%$; Africa $4 \%$; and Europe 37\%. In the Americas, the largest share is in the United States, with 99 centers, followed by Canada with 25 and Brazil with 214 .
In parallel with these new challenges for the health field, the internet and information and communication technologies (ICTs) emerged with the potential to break down geographic, cultural, and economic barriers. In recent decades, new technologies have fostered a new social configuration, with the predominance of networks, whether social, research, community, or professional 5 .

In recent decades, the relationship between health and the internet has fostered an important debate on the role of internet in public participation and the expansion of access to health information for poorer countries $6,7,8$. This debate raises another major concern: access to the web is not universal. According to data for 2011 from Internet World Stats (World Internet Usage and Population Statistics. http://www.internetworldstats.com/ stats.htm (accessed on 21/Mar/2012) 9, 32.7\% of the world population are internet users, a concept that has been described as the "digital divide".

However, there are still various gaps to be explored in the specific relationship between health and the web. Cronin 10 argues that the new model for communication between organizations with the advent of the internet can provide new indicators on the impact and importance of these actors.

Based on this premise, in 2009 the current study focused on the websites of 190 institutions distributed in 52 countries in order to map the Brazilian presence in an international web-based health research network, using a quantitative approach with a focus on webometric techniques.

\section{Methodology}

The study was based mainly on the analytical techniques of webometrics and social networks. Webometrics 11 originated as an area of knowledge from two other areas in the field of information: bibliometrics and informetrics. Webometrics deals with the quantitative aspects of both the construction and use of the web, including four approaches 12: website content analysis, structural analysis of links, analysis of website use (e.g.: analysis of files recording users' search and navigation behavior), and web technology analysis (including search engine performance).

In webometric studies, the link serves as the central analytical unit, based on which it is possible to generate different measures that allow identifying the impact and relevance of websites and their relations in the web, for example.

One method that has been explored in webometric studies is interlink analysis, which allows mapping the volume of links exchanged between two or more sites 13 . This type of analy- 
sis has proven highly useful for studying institutional relations, but its application has still been limited to academia, with a focus on university sites 14,15,16,17,18.

In order to better understand and visualize the flow of information through links exchanged between institutions, the data were also treated with an approach from sociology, social psychology, and anthropology 19,20 known as social network analysis (SNA). Some authors (mostly from the field of educational psychology) had already been working with concepts pertaining to social network analysis since 192219 , but the method's founder considered Jacob Moreno, with the book Who Shall Survive?, published in 1934. Since then, many authors have focused on the technique in order to portray a wide variety of networks, including social interaction (between individuals and institutions), connectivity, collaboration, collective action, trust, and cooperation 21 .

The technique, which has also gained ground among webometric studies 22,23,24,25,26 , is also based on relations between individuals in a given network structure. The concept of individuals is quite flexible, and can be applied to persons, organizations, or groups connected by some type of relationship, and who are called network nodes or actors. The actors play different roles according to the positions they occupy in the network. For example, an actor can serve as a link between other elements that form the component, called a "cut-point" 27.

Two other elements comprise the SNA technique: (1) the intensity of links, which can be weaker or stronger, depending (in the study case) on the number of links exchanged between the actors and (2) the direction of the information flow, which can be unidirectional or bidirectional.

\section{Selection of collaborating centers}

The WHO collaborating centers were chosen as the basis for selecting the study sample, given that institutions designated as collaborating centers or whose structure includes departments designated as such become a reference for cooperation in the field of health. On October 26, 2009 , all the information from the 768 active collaborating centers, representing 89 countries, was collected from the database provided by the WHO. The following information was obtained for each collaborating center: name (of the collaborating center), theme (of the collaboration), contact, institution, address, city, country, date of designation, and website. However, the list obtained from the WHO database contains various inconsistencies: for example, in some cases the website does not match the name of the institution listed by WHO; in others, the website has changed or ceased to exist. The selection of institutions defines "website" as a set of pages housed in the same web domain. The sample thus excluded institutions whose sites do not have their own domain.

Finally, the decision was made for the sample to exclude institutions not exclusively dedicated to the field of health (e.g., universities), since it was impossible to determine the reasons leading to a given network configuration among institutions with widely varied research focuses. The final list for data collection consisted of 354 institutions (with 357 websites, since some institutions had more than one website), from 52 countries.

\section{Data collection}

The data were collected from November 7 to 9 , 2009. Interlinks between all 357 sites were collected using Webometric Analyst (http://lexiurl.wlv.ac.uk, Statistical Cybermetrics Research Group, University of Wolverhampton, UK). An asymmetrical matrix was generated for analysis of interlinks, which includes directionality in the relations between actors. In this phase, the list of centers was reduced again based on adherence to the sample. The filter excluded the centers whose sum in the column number was smaller than the total number of centers in the sample (n) divided by 2 . This process was performed successively until 190 centers remained, representing 42 countries.

\section{Network analysis}

The matrix with interlink totals between pairs of institutions was exported to UCINET (Borgatti SP, Everett MG, Freeman LC; Analytic Technologies, Harvard, USA), which allows calculating different parameters in the social network analysis. The networks were visualized by means of NetDraw, a program incorporated into the UCINET package. In this case, the diagonal of the asymmetrical matrix was adjusted to zero. From this network, four sub-networks were generated that will be the object of this study: an egocentric network with a focus on the Brazilian institutions and three more egocentric networks with the perspective of these institutions. Social networks can be classified as egocentric or sociocentric. Sociocentric networks study the relations between nodes in the network. Egocentric networks focus only on the actors that are linked to a given node in the network, as in the case of the egocentric networks analyzed in this study 19 . 


\section{Results and discussion}

Of the 190 institutions studied here, five were Brazilian: Oswaldo Cruz Foundation (FIOCRUZ-BR), Jorge Duprat Figueiredo Foundation for Work Safety and Medicine (FUNDACENTRO-BR), National Cancer Institute (INCA-BR), Nucleus for Studies on Violence, University of São Paulo (NEV. USP-BR), and Institute of Social Medicine, State University of Rio de Janeiro (IMS-BR). Figure 1 shows the egocentric network obtained for these institutions. The figure allows clearly identifying three of the five Brazilian institutions (gray-colored symbols) occupying outstanding positions in the network. The Brazilian institutions are linked to 44 other institutions, distributed across 21 countries. Table 1 shows all the institutions in this egocentric network, with their respective home countries and acronyms.

Importantly, the size of the nodes (actors/ institutions) varies according to their degree of interconnectedness. FIOCRUZ-BR is the only Brazilian institution occupying a central position in the network, with a relatively high degree of centrality when compared to other institutions that occupy similar positions in the diagram. NEV.USP-BR and IMS-BR have a virtually negligible participation in the network, and are only linked to the component through FIOCRUZ-BR, which acts as a network cut-point in this case.

The Centers for Disease Control and Prevention (CDC-USA), the National Institutes of Health (NIH-USA), and FIOCRUZ-BR are the institutions with the highest degree of interconnection. However, the strongest links are between NIH-USA and seven other institutions, and between the French National Institute for Health and Medical Research (INSERM-FR) and the French National Institute for Agricultural Research (INRA-FR).

\section{Brazilian networks: FIOCRUZ-BR, FUNDACENTRO-BR, and INCA-BR}

Considering that FIOCRUZ-BR, FUNDACENTRO$\mathrm{BR}$, and INCA-BR are the leading Brazilian institutions in the network shown in Figure 1, the networks formed by each of them were isola-

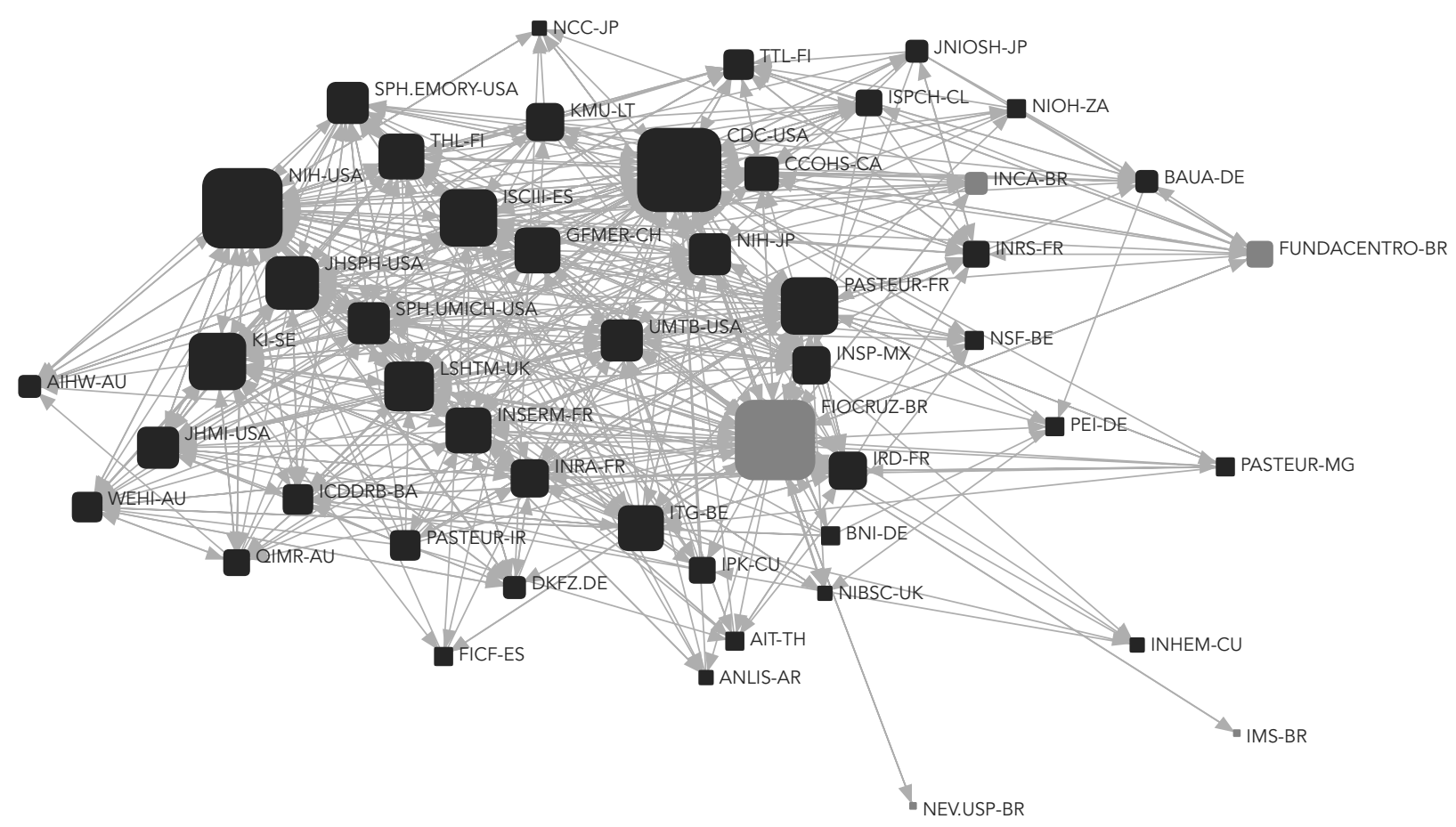


Table 1

Institutions present in the egocentric network of Brazilian institutions.

\begin{tabular}{|c|c|c|}
\hline Institution & Country & Acronym \\
\hline Centers for Disease Control \& Prevention & United States & CDC-USA \\
\hline Canadian Centre for Occupational Health \& Safety & Canada & $\mathrm{CCOHS}-\mathrm{CA}$ \\
\hline Carlos III Health Institute & Spain & ISCIII-ES \\
\hline Finnish Institute of Occupational Health & Finland & TTL-FI \\
\hline Institute of Public Health & Chile & ISPCH-CL \\
\hline Federal Institute of Occupational Safety \& Health & Germany & BAUA-DE \\
\hline National Institute of Occupational Safety and Health & Japan & JNIOSH-JP \\
\hline National Institute for Occupational Health & South Africa & $\mathrm{NIOH}-\mathrm{ZA}$ \\
\hline National Research and Safety Institute & France & INRS-FR \\
\hline School of Public Health, University of Michigan & United States & SPH.UMICH-USA \\
\hline National Institutes of Health & United States & NIH-USA \\
\hline Rollins School of Public Health & United States & SPH.EMORY-USA \\
\hline Bloomberg School of Public Health & United States & JHSPH-USA \\
\hline University of Texas Medical Branch & United States & UTMB-USA \\
\hline Karolinska Institute & Sweden & KI-SE \\
\hline National Cancer Centre & Japan & NCC-JP \\
\hline Nucleus for Studies on Violence & Brazil & NEV.USP-BR \\
\hline Institute of Social Medicine & Brazil & IMS-BR \\
\hline National Institute of Hygiene, Epidemiology and Microbiology & Cuba & INHEM-CU \\
\hline Pasteur Institute of Madagascar & Madagascar & PASTEUR-MG \\
\hline Jorge Duprat Figueiredo Foundation for Work Safety and Medicine & Brazil & FUNDACENTRO-BR \\
\hline Oswaldo Cruz Foundation & Brazil & FIOCRUZ-BR \\
\hline Australian Institute for Health \& Welfare & Australia & AlHW-AU \\
\hline The Walter \& Eliza Hall Institute & Australia & WEHI-AU \\
\hline Queensland Institute for Medical Research & Australia & QIMR-AU \\
\hline Foundation Catalan Institute of Pharmacology & Spain & FICF-ES \\
\hline National Administration of Laboratories and Health Institutes & Argentina & ANLIS-AR \\
\hline Asian Institute of Technology & Thailand & AlT-TH \\
\hline German Cancer Research Centre & Germany & DKFZ-DE \\
\hline National Institute for Biological Standards and Control & England & NIBSC-UK \\
\hline Paul-Ehrlich-Institute & Germany & PEI-DE \\
\hline National Sanitation Foundation & Belgium & NSF-BE \\
\hline National Cancer Institute & Brazil & INCA-BR \\
\hline Kaunas University of Medicine & Lithuania & KMU-LT \\
\hline National Institute for Health and Welfare & Finland & THL-FI \\
\hline Geneva Foundation for Medical Education and Research & Switzerland & GFMER-CH \\
\hline Johns Hopkins Medical Institutions & United States & JHMI-USA \\
\hline International Centre for Diarrhoeal Disease Research & Bangladesh & ICDDRB-BA \\
\hline Pasteur Institute of Iran & Iran & PASTEUR-IR \\
\hline Institute of Tropical Medicine & Belgium & ITG-BE \\
\hline London School of Hygiene \& Tropical Medicine & England & LSHTM-UK \\
\hline Institute of Tropical Medicine Pedro Kouri & Cuba & IPK-CU \\
\hline Bernhard Nocht-Institute for Tropical Medicine & Germany & BNI-DE \\
\hline Research Institute for Development & France & IRD-FR \\
\hline National Institute of Public Health & Mexico & INSP-MX \\
\hline National Institute for Health and Medical Research & France & INSERM-FR \\
\hline Pasteur Institute & France & PASTEUR-FR \\
\hline National Institute for Agricultural Research & France & INRA-FR \\
\hline National Institute of Infectious Diseases & Japan & $\mathrm{NIH}-J \mathrm{P}$ \\
\hline
\end{tabular}


ted, which allowed clearly identifying the main partnerships.

Figure 2 shows the egocentric network formed from FUNDACENTRO-BR, which in Figure 1 occupies the most peripheral position among the Brazilian institutions. Officially created in 1966, FUNDACENTRO-BR is connected to the Brazilian Ministry of Labor and is present in 11 States of Brazil and the Federal District. It became a reference in Latin America in the area of work safety and health, and in 1993 it was designated as a WHO collaborating center, and is now also a collaborating center of the International Labor Organization (ILO) 28.

According to information from the institutional website, FUNDACENTRO-BR conducts cooperation in the area of education and development of projects in environmental management systems with countries of the three Americas, Europe, Japan, and Australia. In fact, network analysis shows FUNDACENTRO-BR linked to FIOCRUZ-BR in Brazil and to ten non-Brazilian institutions from nine countries, including the United States, Canada, European countries, Japan, and South Africa. Except for FIOCRUZBR, CDC-USA, Institute of Public Health, Chile (ISPCH-CL), and the University of Michigan's School of Public Health (SPH.UMICH-USA), which have a broader scope of action, all the other institutions linked to FUNDACENTRO-BR have a specific focus on work safety, which may reflect established partnerships and collaborations. CDC-USA plays the most central role in this egocentric network. The strongest relations are between CDC-USA and the Carlos III Health Institute, Spain (ISCIII-ES).

Occupying a more central position than FUNDACENTRO-BR in the diagram of the network shown in Figure 1 is INCA-BR, an agency affiliated with the Brazilian Ministry of Health in the development and coordination of integrated actions for cancer prevention and control in Brazil. These actions include medical and hospital care provided directly and free of cost to cancer patients as part of the services provided by the Brazilian Unified National Health System (SUS), and action in strategic areas such as prevention and early detection, training specialized health professionals, research, and epidemiological information 29.

Designated as a WHO Collaborating Center for Tobacco Control for the Americas since 1997, INCA-BR plays a strong role in cooperation with other Latin American countries. However, the network formed from INCA-BR consists of eight non-Brazilian institutions, from only four coun-

Figure 2

Egocentric network of the Jorge Duprat Figueiredo Foundation for Work Safety and Medicine (FUNDACENTRO-BR).

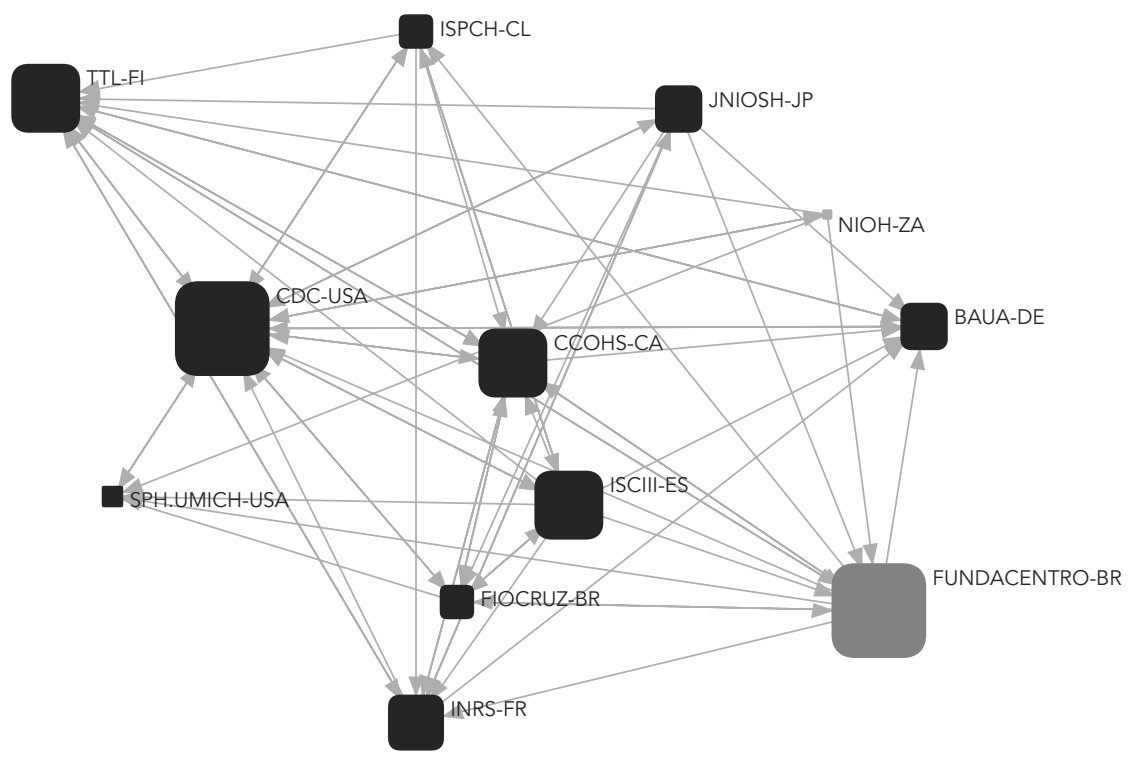


Figure 3

Egocentric network of the Brazilian National Cancer Institute (INCA-BR).

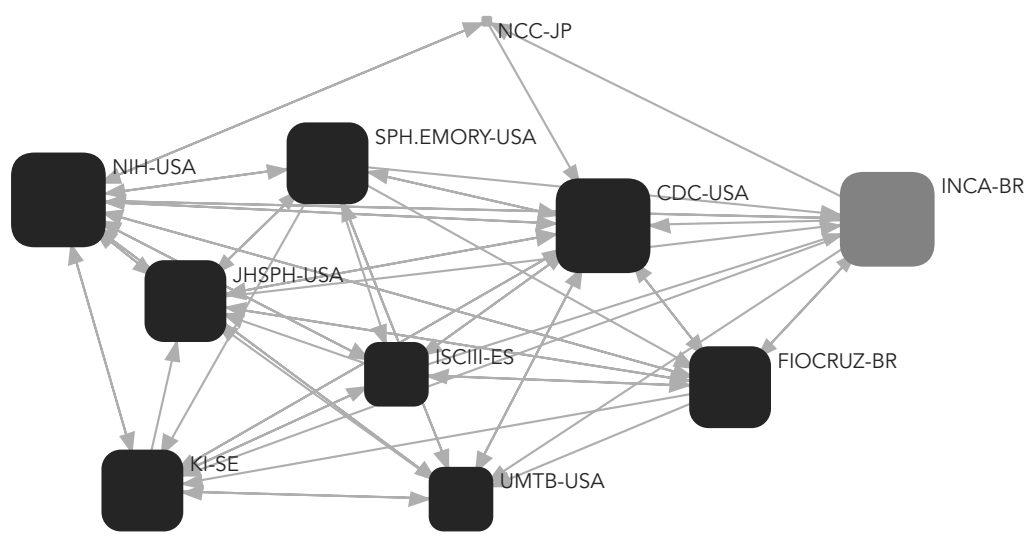

tries, none of them Latin American (Figure 3). The NIH-USA occupies a central position in this network, establishing its most intensive relations with CDC-USA and Karolinska Institute, Sweden (KI-SE).

This connection can be explained by the participation of INCA-BR in the U.S.-Latin America Cancer Research Network 29, the first formal cancer research network between Latin America and the United States, including five Latin American countries and the United States.

The fact that no Latin American institutions appear in the network may be related to the sample selection, since potential Latin American partners of INCA-BR may have been left out of the sample because they lack websites with their own domain or because they are not part of the database of WHO collaborating centers.

Among the Brazilian institutions, INCA-BR only maintains connections to FIOCRUZ-BR. Both are affiliated with the Ministry of Health and have well-established cooperative policies. In 2005, the Brazilian government instituted the National Policy for Cancer Care, and the two institutions joined in a cooperative program to deal with the challenges involved in the development of cancer research. The program includes five research sub-networks: performance assessment of the cancer care network; diagnostic and therapeutic implementation; identification of diagnostic and prognostic markers; development of therapeutic technologies; and identification of genetic and environmental risk factors.

The last egocentric network was formed from FIOCRUZ-BR, an institution affiliated with the
Brazilian Ministry of Health with comprehensive action in the field of health, including activities that range from research to the production of vaccines and medicines, human resources training, and provision of hospital and outpatient referral services 29. The Foundation currently houses WHO collaborating centers in pharmaceutical policies, technical education in health, and leptospirosis, and more recently it was designated as a collaborating center in health and environment.

In its network of web links, FIOCRUZ-BR shares links with 42 institutions, from 20 countries in addition to Brazil (Figure 4). A comparison with the other two networks (Figures 2 and 3) clearly shows the complexity and density of the relations of FIOCRUZ-BR in the web. In this network, NIH-USA and CDC-USA are the leading institutions, although the former occupies a particularly central position. The strongest relations are between CDC-USA and NIH-USA, and between the latter and the following institutions: KI-SE, CDC-USA, National Institute of Infectious Diseases, Japan (NIH-JP), University of Texas Medical Branch, United States (UTMB-USA), INRA-FR, London School of Hygiene and Tropical Medicine, UK (LSHTM-UK), and the Geneva Foundation for Medical Education and Research, Switzerland (GFMER-CH). There is also a particularly strong link between two French institutions: INRA-FR and INSERM-FR.

Among the Brazilian institutions, FIOCRUZBR shows the strongest interconnectedness with other Latin American institutions (from Argentina, Cuba, and Mexico). Just as INCA-BR, 


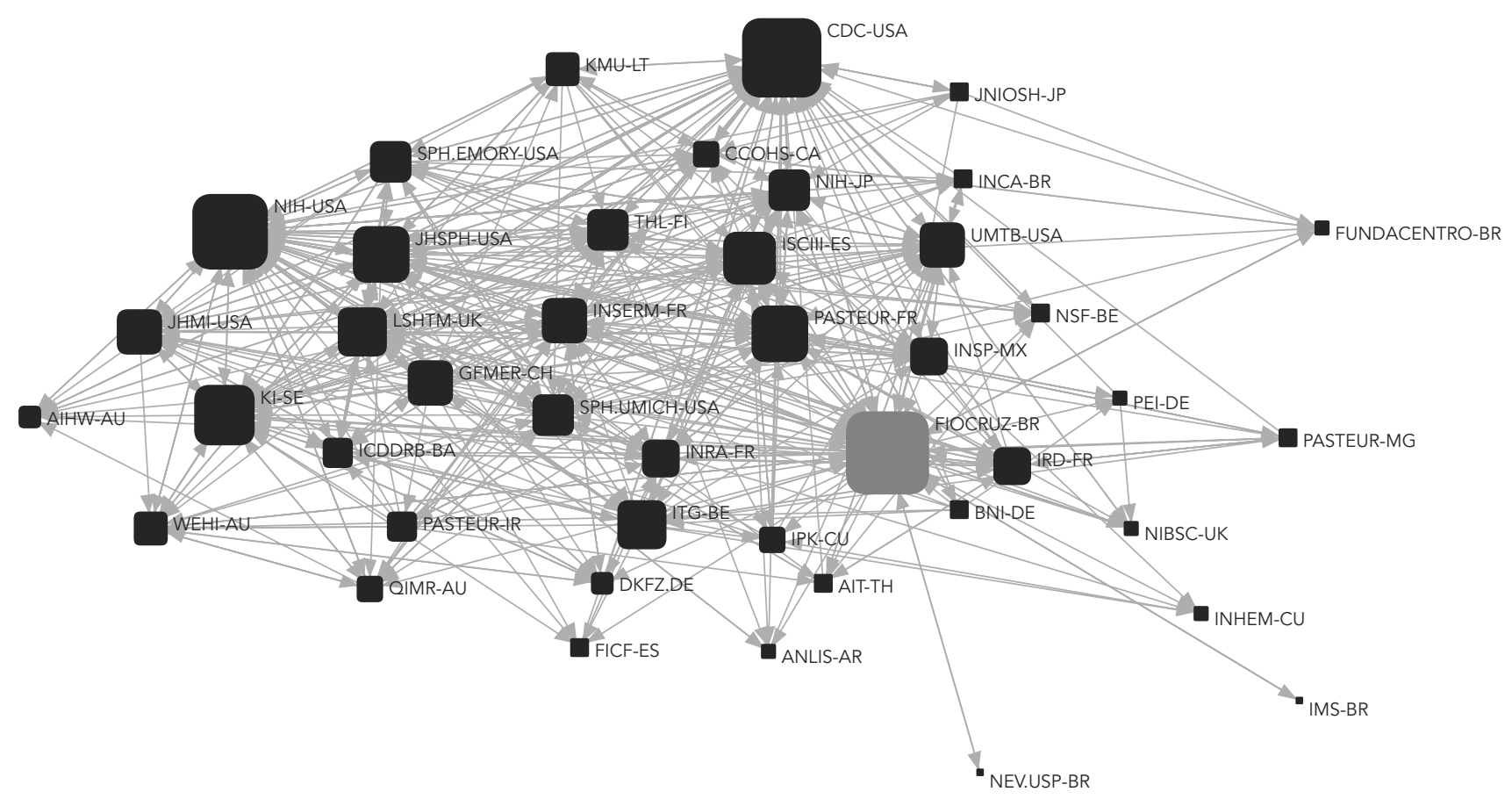

FIOCRUZ-BR has taken the leadership in various Latin American health research networks, with the aim of strengthening South-South cooperation 30. FIOCRUZ-BR also has agreements with research centers and universities from Germany, Belgium, Spain, England, Italy, India, Thailand, South Korea, United States, and Japan. In the United States, the cooperative activities are mainly with NIH-USA and CDC-USA 31.

\section{Final remarks}

Brazil has been acknowledged for fostering international cooperation in health through partnerships, cooperative agreements, and technology transfer with various countries, featuring SouthSouth cooperation 32 . However, the impact of such health cooperation on the internet is still limited to a few Brazilian institutions. Among the main health research institutions, based on those designated as WHO collaborating centers, only five Brazilian institutions were present: FIOCRUZ-BR, FUNDACENTRO-BR, INCA-BR, NEV.USP-BR, and IMS-BR.
Based on the analysis of egocentric networks from three of these five institutions, it was possible to observe some equivalence on the web with many partnerships and forms of cooperation already established between the institutions. Importantly, however, the analysis of frequency of links between these institutions does not allow directing inferring the nature of such relations (whether cooperative or not). Webometrics has been considered a very useful tool for many disciplines that recognize the web's importance as an extension of their research based in real life. However, it is important to recall that the parallel between the real and virtual worlds is not the central objective of webometric studies, which actually aim to investigate the web environment in all its dimensions and contribute to a better understanding of the information flows comprising these virtual networks and to strategies for dealing with the daily challenges raised by new information technologies.

The study also showed limited interlinks between countries of the South.

This may be related to the sample selection, as in the case of INCA-BR, where Latin American 
partners lacked websites with their own domain or were not part of the database of WHO collaborating centers, used as the basis for this study.

Occupying a leading position in the network, FIOCRUZ-BR was the Brazilian institution that had interfaces with the most other institutions. One possible reason is the leading role of FIOCRUZ-BR in policies for the formation of networks in international health cooperation, especially fomenting South-South cooperation 33 . Another reason may be related to the institution's interface with various areas of knowledge production in health science and technology systems 30 , reflecting its multifaceted nature visà-vis the various core activities it conducts.

Regardless of the reasons for this situation and the sample selection's inherent limitations, these results represent an important portrait with the potential to contribute to future analyses and to a strategic plan for repositioning these institutions on the web in order to expand their network of links and further legitimize their partnerships, as well as for the elaboration of public policies and the recognition of applied webometrics as an area to be explored in the interface with various other fields of knowledge.

\section{Resumen}

Con el propósito de mapear la presencia en la web de las instituciones brasileñas, en una red internacional de instituciones de investigación en el campo de la salud, se realizó en 2009 un estudio de 190 instituciones, que representan a 42 países. La muestra fue seleccionada en base a los centros colaboradores de la Organización Mundial de la Salud (OMS) y la metodología se basó en análisis y técnicas webmétricas, especialmente de interlinks y redes sociales. Los resultados muestran la presencia de cinco instituciones brasileñas, en especial de la Fundación Oswaldo Cruz (Fiocruz), que cuenta con conexiones a 20 países y 42 instituciones. A través de la interfaz entre el campo de la salud y de la web, este trabajo pretende contribuir no sólo a un análisis más detallado y un plan de reposicionamiento estratégico de estas instituciones en el mundo virtual, sino también al desarrollo de políticas públicas y el reconocimiento de la webmetría como un área que debe ser investigada y aplicada a otros campos del conocimiento.

Cooperación Internacional; Internet; Red Social

\section{Contributors}

P. B. Lang contributed to the study conceptualization and project, data analysis and interpretation, writing of the article, and approval of the final version for publication. F. C. Gouveia and J. Leta contributed to the study conceptualization and project and revised and approved the version for publication. 


\section{References}

1. Santana JP. Um olhar sobre a cooperação sul-sul em saúde. Ciênc Saúde Coletiva 2011; 16:29933002.

2. Unidade Especial de Cooperação Sul-Sul. Background. http://ssc.undp.org (accessed on 21/ Jan/2012).

3. Associação Brasileira de Cooperação. Histórico. http://www.abc.gov.br/SobreAbc/Historico (accessed on 14/Feb/2012).

4. World Health Organization. WHO Collaborating Centres Database and Portal. http://www.who.int/ whocc (accessed on 21/Jan/2012).

5. Castells M. A sociedade em rede. A era da informação: economia, sociedade e cultura. v. 1. São Paulo: Editora Paz e Terra; 2000

6. Norris P. Digital divide: civic engagement, information poverty, and the internet worldwide. Cambridge: Cambridge University Press; 2001.

7. Morse SS. Global infectious disease surveillance and health intelligence. Health Aff (Millwood) 2007; 26:1069-77.

8. Webster C. The World Wide Web: the great equalizer of the internet, 1995. http://pcinews.com/busi ness/pci/hp/columns/equalizer.html (accessed on 20/Oct/2012).

9. Cronin B. The Warholian moment and other proto-indicators of scholarly salience. J Am Soc Inf Sci 1999; 50:953-5.

10. Almind TC, Ingwersen P. Informetric analyses on the world wide web: methodological approaches to "Webometrics". J Doc 1997; 53:404-26.

11. Thelwall M, Vaughan L, Björneborn L. Webometrics. Annu Rev Inform Sci 2006; 39: 81-135.

12. Lang PB, Gouveia FC, Leta J. Relações intra-institucionais na Internet: um estudo exploratório com base em metodologias webométricas. Perspectivas em Ciência da Informação 2008; 13:137-50.

13. Seeber M, Lepori B, Lomi A, Aguillo I, Barberio V. Factors affecting web links between European higher education institutions. J Informetr 2012; 6:435-47.

14. Holmberg K, Thelwall M. Local government web sites in Finland: a geographic and webometric analysis. Scientometrics 2009; 79:157-69.

15. Ortega JL, Aguillo IF. Análisis estructural de la web académica iberoamericana. Rev Esp Doc Cient 2009; 32:29-65.

16. Tang R, Thelwall M. Disciplinary differences in U.S. academic departmental web site interlinking. Libr Inf Sci Res 2003; 25:437-58.

17. Thelwall M. Evidence for the existence of geographic trends in university web site interlinking. J Doc 2002; 58:563-74.

18. Freeman LC. Some antecedents of social network analysis. Connections 1996; 19:39-42.

19. Wasserman S, Faust K. Social network analysis: methods and applications. Cambridge: Cambridge University Press; 1999. (Structural Analysis in the Social Sciences, 8).
20. Provan K, Fish A, Sydow J. Interorganizational networks at the network level: a review of the empirical literature on whole networks. J Manage 2007; 33:479-516.

21. Kretschmer H, Aguillo I. Visibility of collaboration on the web. Scientometrics 2004; 61:405-26.

22. Kretschmer H, Aguillo I. New indicators for gender studies in web networks. Inf Process Manag 2005; 41:1481-94.

23. Kretschmer H, Kretschmer T. Application of a new centrality measure for social network analysis to bibliometric and webometric data. In: Proceedings of the IEEE International Conference on Digital Information Management. Bangalore: IEEE; 2006. p. 199-204.

24. Ortega L, Aguillo I. Network collaboration in the 6th Framework Programmes: country participation in the health thematic area. Scientometrics 2010; 84:835-44.

25. Vaughan L, Romero-Frias E. Web hyperlink patterns and the financial variables of the global banking industry. Journal of Information Science 2010; 36:530-41.

26. Scott J. Social networks analysis: a handbook. 2nd Ed. London/Thousand Oaks: Sage Publications; 2000.

27. Webometric Analyst. Statistical Cybermetrics Research Group: webometric analyst. http://lexiurl. wlv.ac.uk (accessed on 07/Nov/2009).

28. Borgatti SP, Everett MG, Freeman LC. UCINET for windows: software for social network analysis. Harvard: Analytic Technologies; 2002.

29. Fundação Jorge Duprat Figueiredo de Segurança e Medicina do Trabalho. História. http://www. fundacentro.gov.br/conteudo.asp? $\mathrm{D}=\mathrm{CTN} \& \mathrm{C}=$ 23\&menuAberto $=1$ (accessed on 14/Apr/2012).

30. Instituto Nacional de Câncer; Instituto de Medicina Social, Universidade do Estado do Rio de Janeiro. Sobre o instituto. http://www.inca.gov.br (accessed on 14/Apr/2012).

31. Fundação Oswaldo Cruz. A Fundação. http://por tal.fiocruz.br/pt-br/content/fundação (accessed on 14/Apr/2012).

32. Buss P. Brasil: estruturando a cooperação na saúde. Lancet 2011; 377:1722-3.

33. Fundação Oswaldo Cruz. Relatório de atividades da presidência: 2009-2011. Rio de Janeiro: Fundação Oswaldo Cruz; 2012.

34. Almeida C, Pires de Campos R, Buss PM, Ferreira JR, Fonseca LE. Brazil's conception of SouthSouth "structural cooperation" in health. RECIIS Revista Eletrônica de Comunicação, Informação \& Inovação em Saúde 2010; 4:23-32. http://www. revista.icict.fiocruz.br/index.php/reciis/article/ view/343/528.

Submitted on $17 /$ Sep/2012

Final version resubmitted on 29/Abr/2013

Approved on 12/Jul/2013 